\title{
Very Long Chain Fatty Acids Measurement
}

National Cancer Institute

\section{Source}

National Cancer Institute. Very Long Chain Fatty Acids Measurement. NCI Thesaurus. Code $C 147337$.

The determination of the amount of very long chain fatty acids present in a sample. 